\title{
Situation Analysis and Countermeasures about Physical Dance Course Opened in Hubei College
}

\author{
Youmei ZENG \\ Wuchang Institute Of Technology \\ Wuhan,Hubei, 430065 China
}

\begin{abstract}
Sports Dance is emerging in recent years a sports course, the majority of teachers and students like it. Through literature, interview, investigation and lessons learned in their own work, the Current Situation of Sports Dance Course in Colleges of necessity sports dance courses offered at colleges and universities propose to address sports dance courses to carry out the Problems and Countermeasures.
\end{abstract}

Keywords: Colleges; sports dance classes; analysis; countermeasures

\section{INTRODUCTION}

Sport dance is also called the "international standard dance", and it is a competitive dance project sweeping the world, including Latin and standard dance two types of dance, ballroom dancing (Ballroom) contains a waltz, Viennese waltz, tango, foxtrot and trot dance, Latin dance includes rumba, cha-cha, samba, cowboy and bull dance, sport dance in our country is one of the emerging sports items, it is a deux sports that men and women are as partners. A sport dance is in fusion of music, dance, clothing, demeanor, posture and beauty; both have rich artistic content, and it also has the characteristics of sports competition. In recent years it has become one of the favorite sports of college students in the curriculum; students elect it as popular subjects. Through investigation article by Universities of Hubei Province, the author analysis, and put forward relevant proposals aiming to popularize sport dance in college and to carry out a reference recommendations.

\section{SUBJECTS AND METHODS}

\subsection{SUBJECT}

28 General Colleges opened Dance Sport Course in Hubei Province

\subsection{METHODS}

Literature: consult 40relevant literature data Questionnaire: designed questionnaires and distributed 200 questionnaires, 173 valid questionnaires, the recovery was $86.5 \%$

Interviews: to PEDance university teachers' access to investigate the status quo of Sport Dance Course

Statistics: classify and organize data and questionnaire and recovery literature collected

\section{ANALYSES}

\subsection{ANALYSIS OF HUBEI PE COURSES SITUATION}

Through 28 PEDance teacher interviews in Hubei Province, we concluded that 90 percent of colleges and universities in Hubei sport dance classes are as an elective content, 95 percent of colleges and universities offer courses only one year of sports dance, 40 percent of colleges and 
universities due uneven sex ratio only open rumba and cha dance and Latin dance courses, 20 percent of colleges and universities offer courses only ballroom dancing, many colleges and universities even opened a Latin dance Ballroom, they only opened a few dances, mainly Lombardy, cha-cha, waltz course, only sports dance institutions set up all kinds of dance sport dance courses. Thus, all aspects of college sports dance number of courses, teaching staff, teaching content, teaching methods and teaching conditions have a big difference.

\subsection{STUDENTS, UNDERSTANDING ABOUT THE CURRENT SITUATION AND THE ACTIVITIES OF SPORTS DANCE}

To 173 valid questionnaires for the survey, 8.7 percent of people know nothing about sports dance; people having some understanding of the sport but not familiar accounted for 85.3\%; although $6 \%$ of the students are familiar with sports dance but they can not fully aware of the ten kinds of sport dance. From the analysis of the survey data, there is low awareness of college students understanding of sports dance, ballroom dancing, especially the Foxtrot and Quickstep, most of the students' understanding of sports dance is only through television and other media computer, many students select Physical Dance Course are also just out of curiosity.

Sports dance as an emerging sport, since the 1980s enter college, the majority of teachers and students love it, but due to space, teachers, input costs and other factors limit, the status quo can not meet the university commencement of the needs of students. Students from colleges and universities obtain interviews with teachers, most universities having PEDance only have 1-2 teachers as the school's sports dance classes, each year students choosing PEDdance can not all have the opportunity to learn dance, mostly they can re-election learn from other sports projects. Although many colleges and universities established Dance Sport Association, many students are non-professional sports associations' professional dance, so there is only professor of Latin dance, while the standard dance venues due to female ratio and other issues can not be opened. Overall, to sports dance courses opened in Hubei Province, the domination is Latin and ballroom dancing, and ballroom dancing are of the Open University sports dance professional institutions.

\subsection{SITUATION OF TEACHERS AND TEACHING FACILITIES}

Teachers as the main entire teaching activities, are the designer, organizer, teacher quality throughout the teaching process directly affect the quality of teaching, through the survey, in 28 colleges and universities in Hubei Province, the less the majority of university sports dance professional teachers are made after training or aerobics artistic gymnastics, teacher is as only a small part of University sports dance in colleges graduate teachers. Resulting in relatively there are weak teachers and many colleges and universities only have one sports dance teacher, they teach both men step and women step, the pressure of teaching is larger. In the current sports dance teachers, teachers are hungry for sports dance training or education, but most of the teachers reflect learning and training opportunities to go out much less to continue to study ways, and the training cost spontaneously learning out is higher. Student Sports Association in Hubei Province organizes an annual teacher training and college sports dance tournament, which can not meet the students' strong desire for knowledge for the professional standards of teachers.

Sports Dance Teaching Standards venue is 20 meters long, 15 meters wide and smooth wood floor indoor venues, the venue also needs a mirror, handlebar, audio equipment, sports dance is an emerging sport, which has weak degree of attention in college, many colleges 
and universities offer courses Sports Dance conditions falling far short, backward sports facilities is bound to affect the effectiveness and quality of teaching PE Dance Course.

\subsection{CURRENT SITUATION OF SPORTS DANCE TEACHING}

There are two types of sports dance items, ten kinds of dance, involving rich content, but it is difficult to offer lesson of all universities the physical dance ten kinds of dance classes, so many colleges and universities will be based on school teachers, students, space and other factors and to carry out teaching part of dance, so it will affect the dissemination and popularization of sports dance.

While some colleges and universities opened the sport dance courses, but it is actually a professor of ballroom dancing and will be part of the content or sports dance and ballroom dancing mixed content professor, leading sports dance students learning and cognitive confusion.

In addition, although the establishment of Hubei Province, Hubei Province Dance Sport Association, but there is no uniform universities and sports dance sport dance syllabus course material, many colleges and universities are all teachers according to the actual situation of the school to develop their own curricula, write lesson plans.

\section{COUNTERMEASURES SUGGESTIONS}

AND

Leaders at all levels attach importance to the development of sports dance, organize professional training, introduce specially recruited sports dance teachers, strengthen teachers, promote sports dance teaching and teaching quality.

Teachers use a variety of teaching methods in teaching, combined with modern teaching methods, the introduction of advanced knowledge and professional skills of sports dance, make college sports dance classes to keep up with the trend of social development, improve the teaching of science content, times. While at the same time we increase Sport Dance Course student physical fitness, physical exercises to make students' comprehensive sports dance quality improved.

Promote the sport dance classes to enrich students' second class, universities should engage in more sports dance activities outside the classroom, such as organizing party, the establishment of associations, organizing students to participate in different forms of sports dance competition, Amateur Sports Dance courses, so as to promote exchanges among students, to promote the popularization of sports dance.

Compile uniform materials for College Students in Hubei Province, textbooks are an important basis for teachers in teaching, it is to revise the syllabus, the development progress of the premise of teaching, standardize textbooks and outline sports dance, to improve our Physical Dance Teaching System so that the sports dance get healthy development.

Optimize the teaching environment and teaching condition and increase the construction of stadiums, sports dances efforts to improve basic education conditions for the students to provide a good learning environment.

Sports Dance has a variety of social functions of social, recreational, exercise, athletic performances, it is that people build friendships, strive to exercise an excellent form of exercise. However, due to inadequate sports dance organizations to promote students' ideas, consciousness is not strong enough, and it is difficult for students to be fully aware of the value of sport dance. In addition a large part of University students from rural areas, men and women accept not pro traditional ideas were unable to change, there is a big sports dance obstacle to the performance requirements, it can not be a good course and interpretation required, so to sports dance in addition to classroom learning, we should also increase publicity of the media on sports dance publicity, to further 
improve the sports dance learners and awareness

\section{CONCLUSIONS}

To sport Dance Course in Universities of Hubei Province opened, because time is short, narrow range, leaders at all levels paid insufficient attention to a serious shortage of funding. In the management system biased, outdated ideas of students, faculty weak and uneven seriously restricted the development of sports dance, open status of research through sport dance classes analysis, I believe, to promote the development of sports dance, first teachers should give full play to the initiative, physical dance research and management, enhance teachers quality; secondly the leadership is of importance of sports for dance, increase investment funds to broaden sources of funding; and finally change the students reorganization of the old sports dance known to increase the literacy training efforts of sports dance. By osmosis of sport dance classes, the sports dance project emergences new situation in Hubei College of conduct.

\section{REFERENCES}

[1] Huang Yan. Influence of Sports Dance on the overall quality of university students in science and technology information 20122: 292.

[2] Lin Lin. Sports Dance in Colleges and Universities Present Situation Analysis of Anyang Teachers College [J] 2005 (2):. 119-121

[3] Wang Hongmei, Ma Weidong [J] Physical Dance Teaching Students' Aesthetic Judgment Henan education 20053: 30-31.

[4] Chen Linong Current Situation and Measures for Development of Sports Dance [J] Guangzhou Physical Education Institute, 2001,21 (9): 114

[5] Han Junbo promotes in the university sports dance the significance $[\mathrm{J}]$ Chinese water transport 20064: 224-225.

[6] Zhang Junjie. Physical Dance Teaching aesthetic model [J]. Zhoukou Normal University $2,007,245$ 